\title{
Thai home improvement retailer customer loyalty: A SEM analysis
}

\author{
Atisin Suebsaiaun \\ King Mongkut's Institute of Technology \\ Ladkrabang (KMITL) Bangkok, \\ Thailand \\ 55671171@kmitl.ac.th \\ Thepparat Pimolsathean \\ King Mongkut's Institute of Technology \\ Ladkrabang (KMITL) Bangkok, \\ Thailand \\ theppara@@hotmail.com
}

Abstract. The contest between 'bricks versus clicks', with the disruptive effect of ecommerce on traditional retail formats, is starting to be felt in Thailand. Specifically, home improvement retailers are therefore having to adapt, by creating unique online shopping experiences, which is enhanced by sophisticated electronic customer relationship management (eCRM) systems designed to capture and retain a digitally savvy Thai consumer. Seeing the critical nature if the eCRM process, the researchers undertook an analysis of the opinions of 465 consumers who shopped at one of the five top Thai home improvement retailer stores. Using LISREL 9.10 software to examine the nine hypotheses structural equation model (SEM), it was determined that all the causal factors in the model have a positive influence on customer loyalty, which can be explained by $73 \%$ of the variance in Thai home improvement retailer customer loyalty $\left(\mathrm{R}^{2}\right)$. The causal variables influencing customer loyalty ranked from highest to lowest, were SERVQUAL, customer satisfaction, corporate social responsibility, and eCRM, with a total value of the influence at $0.57,0.38,0.29$ and 0.29 , respectively. Additionally, the study revealed that extreme caution was needed when social media platforms are used in marketing, as overwhelming consumers with poorly targeted, 'spray and pray' style marketing campaigns can generate disenfranchised consumers who unsubscribe from the marketer's channel.

Keywords: corporate social responsibility (CSR), customer loyalty, customer satisfaction, electronic customer relationship management (eCRM), SERVQUAL, Thai, SEM.

JEL Classification: L8, L81, L84, L85, L86, M3 


\section{INTRODUCTION}

According to a Deloitte (2016) Thai consumer survey, it was determined that the urban Thai consumer focus on finding the right product - one that possesses the right set of product attributes to satisfy their unique needs and desires. Moreover, the higher their purchasing power, the greater their willingness to pay for these specific attributes. Also, Thai consumers are a trendy crowd, especially when it comes to consumer electronics and appliances categories. Thai consumers also place a great deal of importance on brand names, with e-commerce purchasing increasing swiftly across all brands (Bharadwaj, Chaudhary, Kittikachorn \& Rastogi, 2017).

Thailand has also become a leader in e-commerce potential in Southeast Asia, currently growing at a 33.5\% annual rate (Electronic Transactions Development Agency, 2016) due to its high penetration numbers in social media (58\%), mobile technologies (149\%), and the Internet (54\%) (Deloittte, 2016). From these totals, we find Thai Generation-Y consumers (Thais born between 1981 and 2000) to be some of the most connected users in the world (Pumim, Srinuan, \& Panjakajornsak, 2017), who are also the largest segment of Thai smartphone owners, which have a lifetime spending potential of over USD \$5 trillion (Siam Commercial Bank Economic Intelligence Center, 2015). This is consistent with Bharadwaj et al. (2017), which stated that a new social media model is driving e-commerce in Thailand, with $40 \%$ of the purchases digitally influenced. Furthermore, Thai consumers report conducting up to $60 \%$ of their online research using websites and apps such as Messenger, Instagram, Line, Kaidee, and Facebook.

Furthermore, these digital citizens have become homeowners, with the Thai home improvement retail sector emerging as a dynamic and competitive one. In greater Bangkok alone, an estimated 80,000100,000 new houses and some 30,000-40,000 new condos are registered every year (Oxford Business Group, 2018). The home improvement industry, therefore, which covers everything from hard goods such as construction materials, bath, and kitchenware, to electrical appliances and soft goods, has rapidly grown in recent years, driven primarily by increasing competition across the country. This is consistent with a Knight-Frank study, in which it was reported that a total of 32,258 units were launched in the second half of 2017 (Figure 1), which is the highest new supply recorded in eight quarters (Siriboon, 2018). As a result, accumulated condominium stock in Bangkok surged to 538,920 units, increasing $6.4 \%$ half on half $(\mathrm{HoH})$.

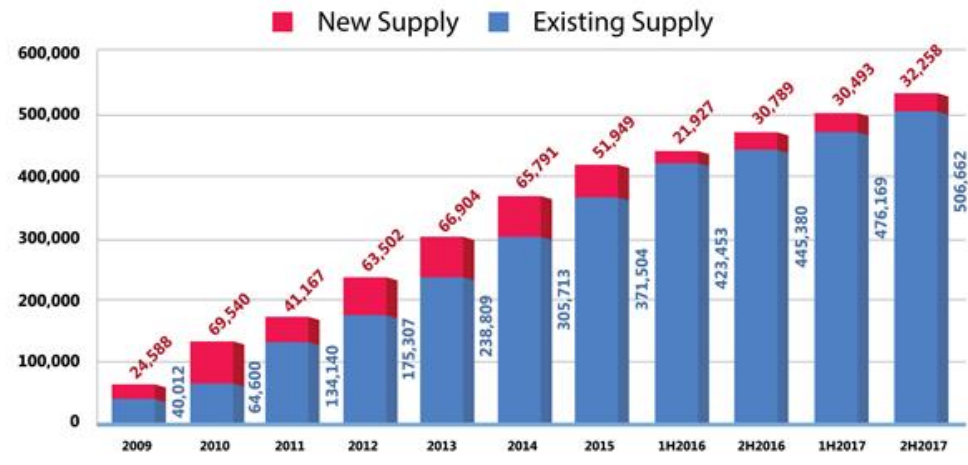

Figure 1. Bangkok condominium support 2009- 2017 Source: Siriboon (2018).

Therefore, higher consumer purchasing power and rapid expansion in residential property development trigger strong growth potential for home improvement retailers. However, the investigation is required to determine how changing technologies affect business service quality, customer service and customer satisfaction (Hallowell, 1996).

While the main reasons for social media are greatly understood, many retailers do not know exactly the key benefits of social media marketing. However, one of the main key benefits of social media marketing is the potential for greater trust between vendors and their customers. Social media can quickly introduce a brand to potential customers, vendors, and partners within their supply chain. Social media 
also creates a digital footprint of the brand and its communication and is a convenient way for consumers to do his or her due diligence on a brand.

In April 2013, Lowes, which is the second largest home improvement retailer in the world, launched their extremely successful 'Fix in six' campaign on the social media channel Vine. From the six-second videos that give tips for home improvement, Lowe's created and shared 115 vines that generated over 65 million views (Girdler, 2016). The company went on to produce a new 'Made in a Minute' video series using Facebook's new 360-degree video feature that generated 4000 shares and 5.7 million views. They also began using Snapchat as a resource for sharing fun how-to's called 'In a Snap', targeted towards younger millennials (aged 18-30). Finally, at the beginning of August 2016 when Instagram released their new Stories feature, Lowes revamped their 'In a Snap' tutorials to be shared there as well.

However, not everyone mirrors Lowe's success, as according to a survey conducted by the North American Retail Hardware Association (NRHA), only 2\% of the respondents identified their social media efforts as excellent, while $46 \%$ classified their efforts as fair or poor (Welter \& Logel, 2016). So, while more retailers are engaging in Facebook, Twitter, Pinterest, and Instagram, most seem to feel they have a long way to go. From the same survey, $86 \%$ of all retailers also indicated they used social media channels for doing business, with $99.5 \%$ of these using Facebook. One retailer comment indicated that although his store only got 500-page likes, he knew of no other way to reach that many people with any other advertising channel.

In Europe, according to Rigby (2018) the major brick-and-mortar home improvement retailer chains of Kingfisher, Bauhaus, and Adeo, hold 93\% of the market share. Although the sector is still sometimes called e-commerce-proof, Amazon will most likely show this to be wrong as well, as in 2017 in Europe, Amazon made 1.4 billion Euro in Home Improvement sales. This is a small fraction of the sales made by the major hardware store chains (commonly called "DIY [do-it-yourself] stores" in continental Europe) but brick-and-mortar sales are only growing at 2\% year-on-year or less. In comparison, Amazon is averaging 30\% plus growth in Europe, which is fifteen times larger than the growth in offline sales. The Home Improvement market is moving online as surely as any other product group. Since Amazon is by far the largest online retailer in Europe, development of new eCRM systems to compete with it, or creating strategic alliances with Amazon, are becoming necessary if home improvement retailers want to remain competitive.

This leads to some unanswered questions concerning the use of social media in electronic customer relationship management (eCRM). The study, therefore, wishes to develop a model of the factors that play a role in the relationship between eCRM and customer loyalty (CL), as well as the factors and relationship between eCRM and customer satisfaction (CS). The study would also like to blaze a trail to determine in what way eCRM influences Thai home improvement retailer corporate social responsibility (CSR). Furthermore, using the globally accepted SERVQUAL Model and its five dimensions, the study would also like to investigate the SERVQUAL Model's relationships with CL, CSR, and CS. Also, finally, the study will seek out what factors influence between CSR and CL and CS, and CS on CL.

\section{LITERATURE REVIEW}

From the analysis of the literature, the following variables were selected as part of the study's framework.

\subsection{Electronic customer relationship management (eCRM)}

Kennedy (2006), stated that customer relationship management (CRM) is about identifying a company's best customers, from which the maximum value is obtained by satisfying and retaining them. Furthermore, eCRM describes the broad range of technologies used to support a company's CRM strategy as they move online, not as a matter of choice, but as a matter of necessity (Feinberg \& Kadam, 2002). Also, eCRM is often referred to as web-enabled or web-based CRM, with Forrester Research defining eCRM as 'a web-centric approach to synchronizing customer relationships across communication 
channels, business functions, and audiences. Today's businesses use the Internet as a channel for commerce and information and an electronic (online/social media) customer relationship management (eCRM) tool (Wang \& Abdullayeva, 2011).

Stephen and Toubia (2010) described social commerce as a new fast-growing trend in the ecommerce market. Today, brick and mortar shops must transform themselves to bridge the gap between the digital and the physical world. Retail customers want access to products, information, trusted opinions, and deals, regardless of whether they are shopping online or in a store. And according to Wang and Abdullayeva (2011), many consumers believe that social networking features to e-commerce enhances the level of trust between a company and its customer. Retailers now can deliver interactive, immersive crosschannel shopping experiences that give their customers the convenience of online shopping in the store.

To do this in Thailand, social media is becoming the platform of choice, with Thailand's most popular social media platform, 'Line', becoming the eCRM of choice (Figure 2) for some home improvement retailers.

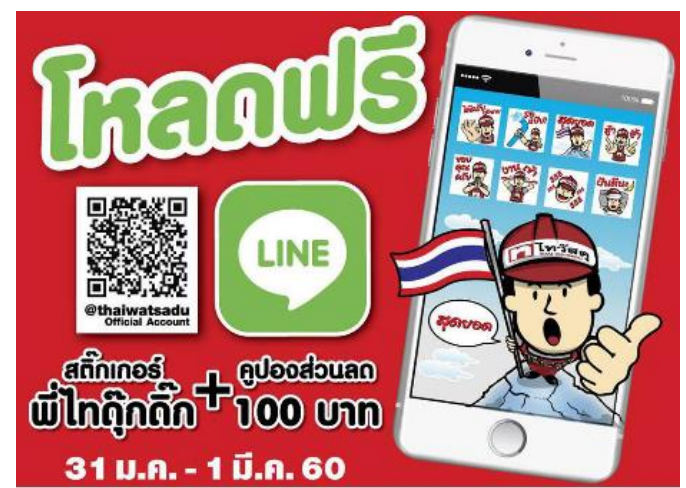

Figure 2. Thai Watsadu's Line Social Media Interface

HomePro has also been an eCRM innovator with the introduction of its Home Service Application which is used as a means of communication for purchasing Home Service via Mobile App. It supports both IOS and Android and covers more than 40 services, as well as 24-hour emergency assistance as well as new services (Figure 3).

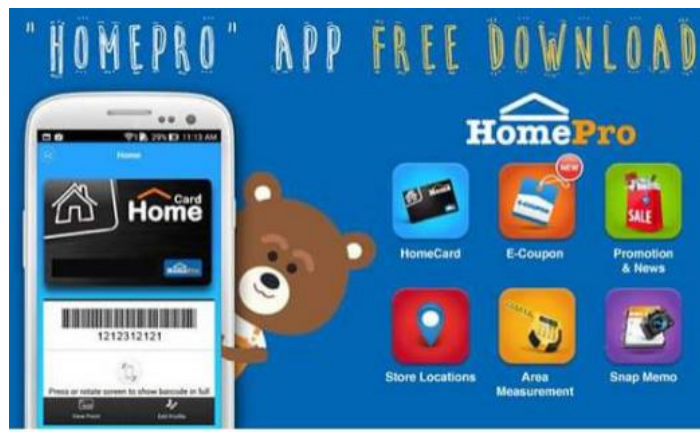

Figure 3. Thailand's HomePro eCRM interface

Therefore, after a review of the relevant literature and theory related to electronic customer relationship management (eCRM), the following three observed variables were included in the research. These included electronic customer relationship management (eCRM), social media (x1), customer relationship management (CRM) (x2), and customer communications (x3). Finally, the following three hypotheses were conceptualized for the research:

H1: Electronic customer relationship management (eCRM) has a direct positive influence on customer loyalty (CL); 
H2: Electronic customer relationship management (eCRM) has a direct positive influence on customer satisfaction (CS);

H3: Electronic customer relationship management (eCRM) has a direct positive influence on corporate social responsibility (CSR).

\subsection{Service quality (SERVQUAL)}

Grönroos (1984) has been credited with the early conceptualization of service quality, which was defined as how consumers receive a service. Originating in Scandinavia, the model was based on a disconfirmation paradigm (Oliver, 1980), by comparing perceived performance and expected service. Later, Grönroos (2001) wrote that the most important characteristic of services is the fact that services are processes, not things. A service firm has no products, only interactive processes. According to Berry, Bennet, and Brown (1989), service quality also leads to customer loyalty and attracts new customers. It also has a positive word-of-mouth influences, and greater employees' satisfaction, improved corporate image, cost reduction and increase in business performance.

It was Parasuraman, Zeithaml, and Berry (1985), however, which published an approach for defining and measuring service quality (The SERVQUAL Model). SERVQUAL indicated that service quality could be measured through five functional quality dimensions (Parasuraman et al., 1988). These included responsiveness, assurance, tangibility, empathy, and reliability (Pena, da Silva, Tronchin, \& Melleiro, 2013). Furthermore, it was indicated that the perceived quality of the product/service is caused by the expectation of customers or clients using the service. Quality is therefore concerned with product longevity and strength, as well as consumer satisfaction in the after-sales service process and through advertisement through word-of-mouth (Alireza, Fatemeh, \& Pegah, 2011).

This is consistent with research from the OECD (2006) in which quality was defined as the totality of features and characteristics of a product or service that bear on its ability to satisfy stated or implied needs. There is also the element of 'functional quality' which is the 'how' component, where 'technical quality' is the 'what' (Kang \& James, 2004).

Service organizations are physical presences that can be seen and felt and are related to the delivery of services. Equipment providers must, therefore, look beautiful, and should provide modern equipment and technology. Materials associated with the service have to be clean, and service staff must have a professional personality and organizations should facilitate both service users and service providers (Parasuraman et al., 1988). This is consistent with Haywood-Farmer (1988), which followed up with research indicating that the three most important attributes in service quality were (1) physical facilities and processes, (2) people's behavior, and (3) professional judgment. SERVQUAL has therefore been widely used to study the broader service industry, where the organization needs to understand the perceptions of its target audience in the service they need and is a technique that provides quality measurement (Ladhari, 2009).

Therefore, after a review of the relevant literature and theory related to service quality (SERVQUAL), the following five observed variables were included in the research. These included reliability ( $\mathrm{x} 4)$, responsiveness (x5), assurance ( $\mathrm{x} 6$ ), empatby ( $\mathrm{x} 7$ ), and tangibility ( $\mathrm{x} 8$ ). Finally, the following three hypotheses were conceptualized for the research:

H4: Service quality (SERVQUAL) has a direct positive influence on customer loyalty (CL);

H5: Service quality (SERVQUAL) has a direct positive influence on corporate social responsibility (CSR);

H6: Service quality (SERVQUAL) has a direct positive influence on customer satisfaction (CS). 


\subsection{Corporate social responsibility (CSR)}

According to Baker (2010), corporate social responsibility (CSR) has no precise definition and is broad in concept. However, in its broadest sense, it is way companies manage their business processes to produce an overall positive impact on society. It covers sustainability, social impact, and ethics. Additionally, according to the Financial Times, it is a movement aimed at encouraging companies to be more aware of the impact of their business on the rest of society, including their stakeholders and the environment. From the World Business Council for Sustainable Development, they defined CSR as the continuing commitment by business to behave ethically and contribute to economic development, while improving the quality of life of the workforce and their families as well as of the local community and society at large (Holme \& Watts, 2000).

However, CSR awards from the Thai American Chamber of Commerce view innovation with a positive social purpose as part of CSR (The Nation, 2017). Companies which pioneer new technologies and business practices that help transform Thailand's economy toward achieving the goals of Thailand 4.0, but also go beyond that to empower communities to help themselves, is what is touted as good Thai CSR.

Historically, Thai company CSR activities have been prominent in external issues, especially community engagement, ethics and child labor, but placed less emphasis on internal issues, such as employees, when compared to other Asian countries (Welford, 2005). This is consistent with Chapple and Moon (2005), which also indicated in Thailand, as well as India and Malaysia, there was a greater emphasis on community involvement, rather than production processes.

Therefore, after a review of the relevant literature and theory related to corporate social responsibility (CSR), the following three observed variables were included in the research. These included the concept of CSR (y8), the readiness to implement CSR ( $\mathrm{y} 9$ ) and patterns of CSR activities (y10). Finally, the following two hypotheses were conceptualized for the research:

H7: Corporate social responsibility (CSR) has a direct positive influence on customer loyalty (CL);

H8: Corporate social responsibility (CSR) has a direct positive influence on customer satisfaction (CS).

\subsection{Customer satisfaction (CS)}

According to Fornell et al. (1996), the first determinant of overall customer satisfaction is perceived quality, with the second determinant being the perceived value. The service management literature also argues that customer satisfaction is the result of a customer's perception of the value received, where value equals perceived service quality relative to price (Cronan, Brady, \& Hult, 2000; Hallowell, 1996). As to the former, Cronan et al. (2000) states that their findings indicate that both service quality and service value lead to customer satisfaction. Also, it is suggested that service quality perceptions are also an important determinant of customer satisfaction.

Customer satisfaction has also been described as a post-choice evaluative judgment concerning a specific purchase selection (Churchill \& Surprenant, 1982; Oliver, 1980). Kotler and Keller (2012, p.128) indicated customer 'satisfaction is a person's feelings of pleasure or disappointment resulting from comparing a product's perceived performance or outcome concerning his/her expectations'. Satisfaction also reflects a person's judgment of a product's perceived performance concerning expectations. A vendor's price should also match well with the offer's perceived value; otherwise, buyers will turn to a competitor's products. Additionally, there is growing empirical evidence that emotion, based on consumption, impacts a consumer's satisfaction judgment as well (Mano \& Oliver, 1993; Oliver, 1994).

Therefore, after a review of the relevant literature and theory related to customer satisfaction (CS), the following three observed variables were included in the research. These included the perceived quality (y5), 
perceived value (y6), and perceived expectations (y7). Finally, the following hypothesis was conceptualized for the research:

H9: Customer satisfaction (CS) has a direct positive influence on customer loyalty (CL).

\subsection{Customer loyalty (CL)}

According to Kotler and Keller (2012), many consumers today feel there are less real product differences, so consumers show less brand loyalty and become more price and quality-sensitive in their search for value, and less tolerant about undesired marketing. However, holistic marketers can succeed by managing a superior value chain that delivers a high level of product quality, service excellence, and speed. They achieve profitable growth by expanding customer share, building customer loyalty, and capturing customer lifetime value. This is consistent with Thaichon, Lobo, and Mitsis (2014), whose study proposes that by enhancing service quality, firms can influence customers' satisfaction, trust, commitment and value, and ultimately their customer's loyalty. Furthermore, Khadka and Maharjan (2017) stated that if a customer's satisfaction is earned, then it is sure that customer loyalty will also come along with it. Also, increased customer satisfaction can provide company benefits like customer loyalty, which creates customer repurchase intention and the customer's positive word of mouth communication.

Therefore, after a review of the relevant literature and theory related to customer loyalty (CL), the following four observed variables were included in the research. These included repurchase intention (y1), consumer trust (y2), service excellence (y3), and word of mouth (y4).

\subsection{The research framework}

Model and hypotheses development, therefore, came from electronic customer relationship management (eCRM), the service quality SERVQUAL Model (SERVQUAL), customer loyalty (CL), customer satisfaction (CS), and their effects on Thai home improvement retailer customer loyalty (CL). From this, the following hypotheses and conceptual framework were developed (Figure 4):

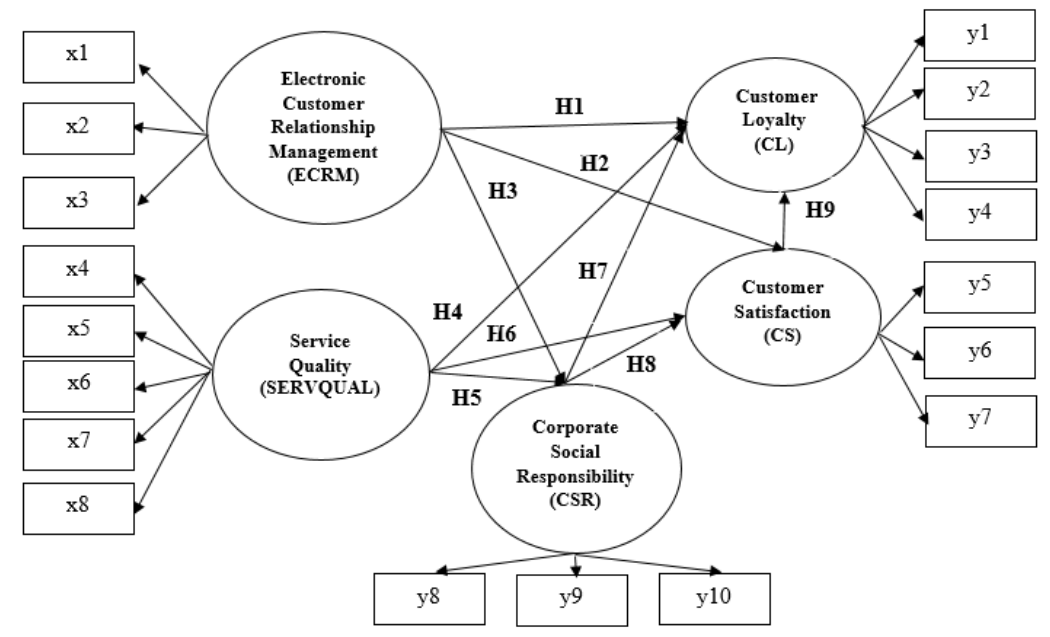

Figure 4. The nine hypotheses conceptual framework 


\section{METHODOLOGY}

\subsection{Population and sample}

According to Pituch and Stevens (2016), a good general rule for sample size is 15 cases per predictor in a standard ordinary least squares multiple regression analysis. According to Mertler (2016), in education research, if population size is around 1,500, a sample size of 300 is adequate. Also, beyond a certain point $(\mathrm{n}=5,000)$, the population size becomes irrelevant, and a sample size of 400 will be adequate. Increasing the size of the sample beyond this point is not critical, but doing so will increase the confidence with which the researcher can generalize results. Therefore, as the study contained 18 observed variables, even by increasing the multiple to 20 questionnaires per observed variable, 360 was the number originally targeted. However, to assure maximum reliability within the survey process as the research team had limited time and access to each home improvement retailer facility, a higher target was set to 500 as shown in Table 1.

Table 1, therefore, shows the provinces and home improvement retailers targeted for sample collection. From the use of multi-stage random sampling, 500 questionnaires were collected. The six target provinces included Bangkok, Samut Prakan, Nonthaburi, Samut Sakhon, Pathum Thani and Nakhon Pathom. The home improvement retailer customers included HomePro, Thai Watsadu, Siam Global House, Mega Home, and Dohome.

Table 1

Thai Home Improvement Company Retailer Customers Surveyed $(n=500)$

\begin{tabular}{|l|c|c|c|c|c|c|}
\hline \multicolumn{1}{|c|}{ Provinces } & HomePro & Thai Watsadu & Global House & Dohome & Mega Home & Total \\
\hline Bangkok & 40 & 15 & NA & NA & 7 & 62 \\
\hline Samutprakan & 40 & 15 & 27 & NA & NA & 82 \\
\hline Nonthaburi & 40 & 15 & NA & 25 & NA & 80 \\
\hline Samutsakhon & 40 & 15 & NA & 25 & NA & 80 \\
\hline Pathumthani & 40 & 15 & 27 & 25 & 7 & 114 \\
\hline Nakhonpathom & 40 & 15 & 27 & NA & NA & 82 \\
\hline \multicolumn{1}{|c|}{ Total } & 240 & 90 & 81 & 75 & 14 & 500 \\
\hline
\end{tabular}

$\mathrm{NA}=$ not applicable, which means this company at the time of the survey did not have a store in this area. Both Global House and Dohome focus outside Bangkok.

\subsection{Research instrument}

A five-level Likert agreement scale was used to evaluate Thai home improvement retailer customer loyalty (CL), with ' 1 ' indicating 'strongly disagree', ' 3 ' indicating a 'moderate' agreement, and ' 5 ' representing a response of 'strongly agree'. The online survey also consisted of two parts. Part 1 consisted of the customer's personal and shopping characteristics and contained nine items (Appendix 1). Part 2 consisted of six sections containing a total of 92 items. This included eCRM with 15 items, SERVQUAL with 26 items, CL with 23 items, CSR with 13 items, and finally, CS with 15 items. The Thai language questionnaire can still be found online at https://goo.gl/forms/Wt4ICE7kQvzd1R9G2

\subsection{Instrument design process}

The Thai home improvement retailer customer loyalty questionnaire items were extracted after an examination of the literature's theory. Questionnaire validity was determined by interviews with five experts in their related fields, and the use of the Index of Item Objective Congruence (IOC). This 
included two academic experts, and three executives, including one from Home Pro, a second expert from Thai Watsadu, and the third from Mega Home. Further verification came from a 34-individual test (tryout) not used in the subsequent study. The IOC used in conjunction with the expert group was tasked with evaluating the content of the survey's items. By definition, an IOC scores greater or equal to 0.50 is considered acceptable, with items with an IOC less than 0.50 either being rejected or revised (Tavakol \& Dennick, 2011). From the five experts, questionnaire item scores ranged between 0.80 and 1.00 , which is deemed reliable (Kline, 2011).

\subsection{Data collection}

The process of data collection for the study began with a sample survey which had to be approved by the university management board. This was followed by applying for permission from the targeted home improvement retailer home offices, with subsequent visits to each of the targeted store's management. The retailers selected for the study came from their respective market shares, which at the time of the survey was as follows: 1. HomePro (9.97\%), 2. Thai Watsadu (3.89\%), 3. Global House (3.36\%), 4. DoHome (3.15\%), 5. Mega Home (0.59\%) (GSB Research, 2016).

From April - May 2018, the survey team went to the selected store every day, from opening to noon. From their positions at the store entrance, the survey team was able to intercept customers to elicit their participation. They were given the opportunity to fill out the survey online or by use of a paper questionnaire on a clipboard. Team members were always available to answer any questions and to verify questionnaire completion. After the allocated period of two months, 500 questionnaires had been collected. However, after an audit of the questionnaires, 465 were deemed useable. This represented a $93 \%$ completion rate of the 500 targeted.

\subsection{Data analysis}

Borrowing on similar regional studies concerning consumer/customer loyalty (Ngo \& Pavelková, 2017), the sample of 465 was judged to be highly reliable, with structural equation modeling (SEM) being an analysis method of choice in all of the cases studied. SEM is also a more powerful alternative to multiple regression, path analysis for examining the complex interrelationships between constructS. Before SEM analysis, however, confirmatory factor analysis (CFA), reliability and validity analysis is performed to assess the adequacy of the measurement model for each research model. If the models have adequate fit with data, the structural models are tested to assess the significance of relationships within each research model.

\section{RESULTS}

\subsection{Customer descriptive statistics $(n=465)$}

After an audit of the 500 questionnaires collected, 465 were deemed to be usable for the study. From this, $56.10 \%$ were men, while $43.90 \%$ were women. The majority were between $31-40$ years of age $(35,30 \%)$ and had at least a four-year university degree $(61.70 \%)$. Also, a large percentage $(58.30 \%)$ were employed in private companies, with an amazing $73.30 \%$ of those surveyed stating they owned their own homes, while $76.30 \%$ said they only shopped on the weekends. The complete and lengthy shoppers' characteristics can be found in Appendix 1. 


\subsection{Confirmatory factor analysis (CFA) results}

A CFA was carried out using structural equation modeling (SEM) with LISREL (LInear Structural RELationships) 9,10 to examine the general fit of the proposed model with data and to identify the overall relationships among these constructs (Byrne, 2010; Diamantopoulos \& Siguaw, 2000; Jöreskog \& Sörbon, 2015). As suggested by Anderson and Gerbing (1998), a 2-step analysis is conducted in which analysis of the measurement model and both sets of dependent and independent variables are conducted separately (Table $2 \&$ Table 3). In the second step, the analysis of the structural equation model (SEM) of the two competing models of customer loyalty (CL) is measured.

Table 2

CFA of Independent (External) Latent Variables

\begin{tabular}{|l|c|c|c|c|c|c|}
\hline \multicolumn{1}{|c|}{ Construct } & $\alpha$ & CR & AVE & Observed variables & loading & $\mathrm{R}^{2}$ \\
\hline eCRM & 0.91 & 0.87 & 0.68 & Social media (x1) & 0.76 & 0.59 \\
\cline { 2 - 7 } & & & & $\begin{array}{c}\text { Customer relationship management (CRM) } \\
\text { (x2) }\end{array}$ & 0.84 & 0.71 \\
& & & & Customer communication (CC) (x3) & 0.87 & 0.75 \\
\hline SERVQUAL & 0.96 & 0.95 & 0.78 & Reliability (x4) & 0.91 & 0.83 \\
\cline { 2 - 7 } & & & & Responsiveness (x5) & 0.84 & 0.70 \\
\cline { 2 - 7 } & & & & Assurance (x6) & 0.90 & 0.81 \\
\cline { 2 - 7 } & & & & Empathy (x7) & 0.89 & 0.80 \\
\cline { 2 - 7 } & & & & Tangibles (x8) & 0.87 & 0.76 \\
\hline
\end{tabular}

Chi-Square $=4.36, \mathrm{df}=10, p$-value $=0.92945$, RMSEA $=0.000$

Table 3

CFA of Dependent (Internal) Latent Variables

\begin{tabular}{|l|c|c|c|l|c|c|}
\hline \multicolumn{1}{|c|}{ Construct } & $\alpha$ & CR & AVE & \multicolumn{1}{c|}{ Observed variables } & loading & $\mathrm{R}^{2}$ \\
\hline CL & 0.96 & 0.85 & 0.59 & Repurchase intention(y1) & 0.87 & 0.75 \\
\cline { 2 - 7 } & & & & Consumer trust (y2) & 0.87 & 0.76 \\
\cline { 2 - 7 } & & & & Service excellence (y3) & 0.82 & 0.67 \\
\cline { 2 - 7 } & & & & Word-of-mouth (y4) & 0.43 & 0.18 \\
\hline \multirow{4}{*}{ CS } & 0.96 & 0.85 & 0.66 & Perceived Quality (y5) & 0.84 & 0.72 \\
\cline { 2 - 7 } & & & & Perceived Value (y6) & 0.76 & 0.72 \\
\cline { 2 - 7 } & & & & Perceived Expectation (y7) & 0.57 \\
\hline CSR & 0.95 & 0.86 & 0.67 & Comments on the concept of CSR(y8) & 0.85 & 0.77 \\
\cline { 2 - 7 } & & & & Readiness to implement CSR concept (y9) & 0.83 & 0.69 \\
\cline { 2 - 7 } & & & & Patterns of CSR activities (y10) & &
\end{tabular}

Chi-Square $=6.46, \mathrm{df}=16, p$-value $=0.98227, \mathrm{RMSEA}=0.000$.

In SEM, CFA is usually used to access construct validity (Jöreskog \& Sörbom, 2015), with factor loadings or regression weight estimates of latent to observed variables having values greater than 0.50 indicating that all of the constructs conform to the construct validity test (Byrne, 2010; Hair, Hult, Ringle, \& Sarstedt, 2016). The criteria for determining the variables each have validity convergence to have the AVE higher than 0.50 as well (Hair et al., 2016), which was confirmed in Table 4. 
Table 4

Correlation Coefficients between Latent Variables (beneath the diagonal), Construct Reliability $(\rho C)$ and the Average Variance Extracted (AVE)

\begin{tabular}{|l|l|l|l|l|l|}
\hline \multicolumn{1}{|c|}{ Latent variables } & \multicolumn{1}{c|}{ CL } & \multicolumn{1}{c|}{ CS } & \multicolumn{1}{c|}{ CSR } & \multicolumn{1}{c|}{ SERVQUAL } & eCRM \\
\hline CL & $\mathbf{1}$ & & & & \\
\hline CS & $.747^{* *}$ & $\mathbf{1}$ & & & \\
\hline CSR & $.635^{* *}$ & $.680^{* *}$ & $\mathbf{1}$ & & \\
\hline SERVQUAL & $.724^{* *}$ & $.818^{* *}$ & $.589^{* *}$ & $\mathbf{1}$ & \\
\hline eCRM & $.637^{* *}$ & $.756^{* *}$ & $.590^{* *}$ & $.742^{* *}$ & $\mathbf{1}$ \\
\hline$\rho_{\mathrm{C}}($ Construct Reliability) & 0.85 & 0.85 & 0.86 & 0.95 & 0.87 \\
\hline$\rho_{\mathrm{V}}(\mathrm{AVE})$ & 0.59 & 0.66 & 0.67 & 0.78 & 0.68 \\
\hline$\sqrt{\mathrm{AVE}}$ & 0.77 & 0.81 & 0.82 & 0.88 & 0.83 \\
\hline
\end{tabular}

$* *$ Sig. $<.01$.

\subsection{The Direct Effect (DE), Indirect Effect (IE), and Total Effects (TE)}

Table 7 shows the DE, IE, and TE of each construct with the sum of direct and indirect effects is referred to as the total effect (Bollen, 1987). The " $p$ " value is the 'level of significance' with a $p<0.05$ indicating that the probability that the result is observed due to chance is $5 \%$ (a "false positive" result). According to Olobatuyi (2006), the independent variable that has the greater coefficient (TE) accounts for more variance in the dependent variable or is the more important cause of the dependent variable. Table 7, therefore, shows CL is influenced by the direct positive influence of SERVQUAL due to the TE value of 0.57. CS also has a direct positive relationship with SERVQUAL, as indicated by the TE value of 0.67. CSR was finally determined to be influenced nearly equally by both eCRM (0.39) and SERVQUAL (0.36).

\subsection{Structural equation modeling (SEM) results}

The SEM results in Figure 3 are from the analysis of the variables effects on Thai home improvement retailer customer loyalty.

Table 5

DE, IE, and TE from Path Model Analysis ( $\mathrm{n}=465)$

\begin{tabular}{|c|c|c|c|c|c|c|}
\hline \multirow{2}{*}{$\begin{array}{c}\text { Dependent } \\
\text { variables }\end{array}$} & \multicolumn{6}{|c|}{ Independents } \\
\hline & & $\mathrm{R}^{2}$ & $\mathrm{CS}$ & CSR & SERVQUAL & eCRM \\
\hline \multirow{3}{*}{ Customer loyalty (CL) } & $\mathrm{DE}$ & \multirow{3}{*}{.73} & $0.38^{*}$ & $0.19 *$ & $0.25^{* *}$ & 0.10 \\
\hline & IE & & - & 0.10 & $0.32^{*}$ & $0.19 * *$ \\
\hline & TE & & $0.38^{*}$ & $0.29 * *$ & $0.57 * *$ & $0.29 * *$ \\
\hline \multirow{3}{*}{ Customer satisfaction (CS) } & $\mathrm{DE}$ & \multirow{3}{*}{.92} & & $0.26^{* *}$ & $0.57 * *$ & $0.22^{* *}$ \\
\hline & $\mathrm{IE}$ & & & - & $0.10^{* *}$ & $0.10^{* *}$ \\
\hline & TE & & & $0.26^{* *}$ & $0.67 * *$ & $0.32 * *$ \\
\hline \multirow{3}{*}{ Corporate social responsibility (CSR) } & $\mathrm{DE}$ & & & & $0.36^{* *}$ & $0.39 * *$ \\
\hline & IE & .51 & & & - & - \\
\hline & TE & & & & $0.36^{* *}$ & $0.39 * *$ \\
\hline
\end{tabular}

$*$ Sig. $<0.05, * *$ Sig. $<0.01$, SERVQUAL - service quality, eCRM = electronic customer relationship management.

The results showed that all models met the required criteria as the chi-square index was not statistically significant at 69.47 , the $p$-value was $=0.744$, the root mean square error of approximation 
$($ RMSEA $)=0.00$, goodness of fit index $(\mathrm{GFI})=0.98$, adjusted goodness of fit index $(\mathrm{AGFI})=0.96$, and the standardized root mean square residual $(\mathrm{SRMR})=0.01$ (Table 6$)$. Therefore, all causal factors in the model had a positive influence on the CL, which can explain $73 \%$ of the variance in Thai home improvement retailer customer loyalty $\left(\mathrm{R}^{2}\right)$ (Table 5). The causal variables influencing CL ranked from highest to lowest were SERVQUAL, CS, CSR, and eCRM, with a total value of the influence at $0.57,0.38$, 0.29 and 0.29 , respectively.

Table 6

Criteria, Values, Results, and Theory of the Values of Goodness-of-Fit Appraisal

\begin{tabular}{|l|c|c|c|c|}
\hline \multicolumn{1}{|c|}{ Criteria Index } & Criteria & Values & Results & Supporting theory/comments \\
\hline Chi-square $(\chi 2)$ & $(\mathrm{p}>0.05)$ & 69.47 & passed & (Jöreskog \& Sörbon, 2015) \\
\hline Relative $\chi^{2}-\chi^{2} / \mathrm{df}$ & $\leq 2.00$ & 0.89 & passed & (Byrne, 2010) \\
\hline GFI & $\geq 0.90$ & 0.98 & passed & (Jöreskog \& Sörbon, 2015) \\
AGFI & $\geq 0.90$ & 0.96 & passed & (Baumgartner \& Hombur, 1996) \\
\hline RMSEA & $\leq 0.06$ & 0.00 & passed & (Hu \& Bentler, 1999) \\
\hline SRMR & $\leq 0.05$ & 0.01 & passed & (Diamantopoulos \& Siguaw, 2000) \\
\hline Cronbach's Alpha & $\geq 0.80$ & $0.91-0.96$ & passed & (Tavakol \& Dennick, 2011) \\
\hline
\end{tabular}

Hypotheses testing results from the use of LISREL 9.1 are summarized in Figure 5 and Table 7.

Table 7

Results of the Hypothesis Testing

\begin{tabular}{|l|c|c|c|}
\hline \multicolumn{1}{|c|}{ Hypotheses } & Coef. & t-test & Results \\
\hline $\begin{array}{l}\text { H1: Electronic customer relationship management (eCRM) has a direct positive } \\
\text { influence on customer loyalty (CL). }\end{array}$ & 0.10 & 1.41 & Inconsistent \\
\hline $\begin{array}{l}\text { H2: Electronic customer relationship management (eCRM) has a direct positive } \\
\text { influence on customer satisfaction (CS). }\end{array}$ & 0.22 & $4.00^{* *}$ & Consistent \\
\hline $\begin{array}{l}\text { H3: Electronic customer relationship management (eCRM) has a direct positive } \\
\text { influence on corporate social responsibility (CSR). }\end{array}$ & 0.39 & $4.87 * *$ & Consistent \\
\hline $\begin{array}{l}\text { H4: Service quality (SERVQUAL) has a direct positive influence on customer } \\
\text { loyalty (CL). }\end{array}$ & 0.25 & $2.06^{*}$ & Consistent \\
\hline $\begin{array}{l}\text { H5: Service quality (SERVQUAL) has a direct positive influence on corporate social } \\
\text { responsibility (CSR). }\end{array}$ & 0.36 & $4.70^{* *}$ & Consistent \\
\hline $\begin{array}{l}\text { H6: Service quality (SERVQUAL) has a direct positive influence on customer } \\
\text { satisfaction (CS). }\end{array}$ & 0.57 & $10.29 * *$ & Consistent \\
\hline $\begin{array}{l}\text { H7: Corporate social responsibility (CSR) has a direct positive influence on customer } \\
\text { loyalty (CL). }\end{array}$ & 0.19 & $2.56^{*}$ & Consistent \\
\hline $\begin{array}{l}\text { H8: Corporate social responsibility (CSR) has a direct positive influence on customer } \\
\text { satisfaction (CS). }\end{array}$ & 0.26 & $5.57 * *$ & Consistent \\
\hline $\begin{array}{l}\text { H9: Customer satisfaction (CS) has a direct positive influence on customer loyalty } \\
\text { (CL). }\end{array}$ & 0.38 & $2.04^{*}$ & Consistent \\
\hline
\end{tabular}

$*$ Sig. $<0.05, * *$ Sig. $<0.01$. 


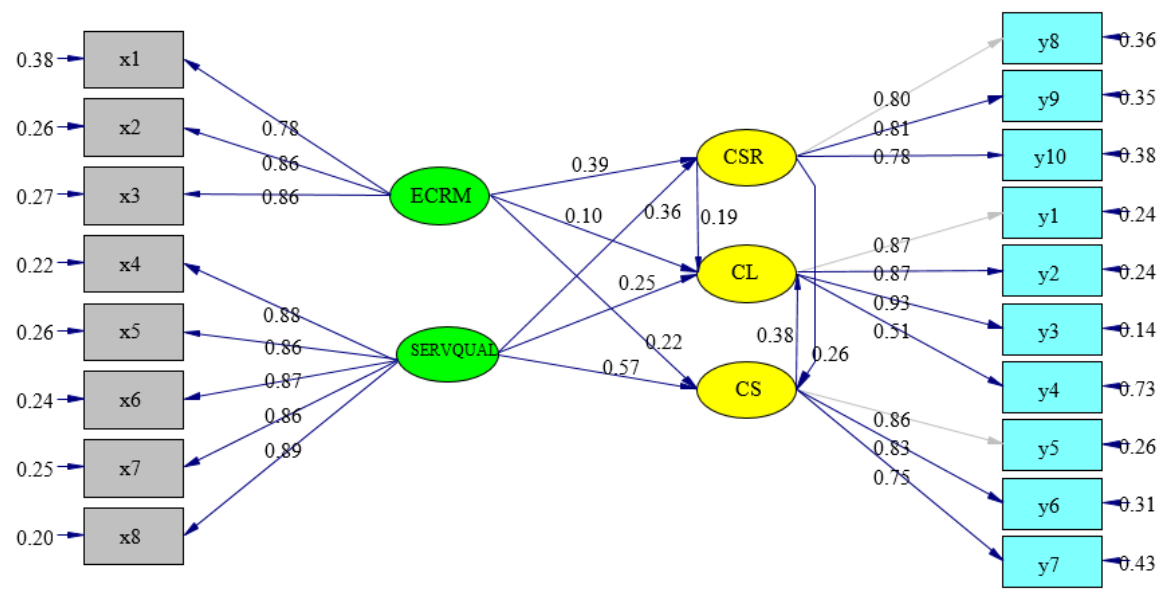

Figure 5. Final model

Chi-Square $=69.47, \mathrm{df}=78, p$-value $=0.744$, RMSEA $=0.000$.

\section{DISCUSSION}

According to Prahalad and Hamel (1990), a corporate core competency has three characteristics. These include: (1) It is a source of competitive advantage and makes a significant contribution to perceived customer benefits, (2) it has applications in a wide variety of markets, and, (3) it is difficult for competitors to imitate.

\subsection{Electronic customer relationship management (eCRM)}

According to the results from the three hypotheses (H1-H3) concerning eCRM, eCRM's role in customer loyalty (CL), customer satisfaction (CS), and corporate social responsibility (CSR) were mixed. Bharadwaj et al. (2017), noted that in Thailand a new social media model is driving e-commerce, with new trends - and their strategic implications - providing critical input for companies seeking to expand their reach and share of a consumer's wallet in Thailand. Thai consumers are also the most brand-conscious and brand-loyal consumers in the region, with many consumers loving the convenience of shopping online using laptops or mobile phones. This helps them avoid some of the most congested traffic in the world, while also making use of the online social media model a treasure hunt and an adventure.

In the rejection of $\mathrm{H} 1$ however, this is consistent with other global studies which advise caution in the use of social media advertising. The reasons for this are that consumers can be overwhelmed with social media advertising, which can lead to consumers unsubscribing from the retailer or brand (Skeldon, 2017). Therefore, poorly targeted, 'spray and pray' style marketing campaigns generate the most spam complaints, and the majority of such communications remain unopened.

Concerning $\mathrm{H} 2$ and eCRM's positive relationship with CS, global studies have also shown the importance of social media platforms to retail firms when utilized correctly (Windsor, 2017). When retailers use these tools correctly, $57 \%$ of UK consumers surveyed said they are more likely to buy from brands they follow on social media, while $75 \%$ reported that purchases were based on something they saw on social media. Additionally, social media is not just for the young, as a Nielsen (2017) study indicated that both Generation X and Generation Y use it (20-50 years old).

Furthermore, in a Thai hotel industry study concerning their use of eCRM, it was stated that five main dimensions lead to eCRM success. This included organization readiness, customer service, 
knowledge management, online communication, and technology support (Cherapanukorn, 2017). Other recent Thai research also confirms eCRM's (social media) importance, as at the end of 2017 among 2,000 Thai businesses across all industries, Thai businesses reported the following statistics (Techsauce Team, 2018):

- $89 \%$ of workers said their business is using social media platforms of some kind in their business or organization. This is across all business sizes - small, medium and large.

- $71 \%$ reported that social media is used daily in their business.

- $58 \%$ claimed it benefits their business significantly.

- For external communication, 58\% of businesses are using LINE, $43 \%$ are using Email, and 35\% are using Facebook.

Concerning H3's positive relationship between eCRM and CSR, this is consistent with a Nielsen survey in which $66 \%$ of consumers from 60 countries said they are willing to pay more for sustainable brands manufactured by a company that was socially and/or environmentally responsible (Nielsen, 2015). CSR, therefore, can be a factor that differentiates one seller from another in a crowded marketplace.

\subsection{Service quality (SERVQUAL)}

The SERVQUAL scale which was developed in 1988, has been found to be usefectiveul for measuring perceptions and expectations of the users about service quality (Marshall \& Murdoch, 2001). From the use of this measurement tool in the study, three hypotheses were generated, all of which were found to have positive relationships. Investigations have also confirmed that reliability is the most critical dimension, and tangibility is less relevant to the service quality from the user's perception (Parasuraman et al., 1985).

From H4's analysis, SERVQUAL was determined to have a positive influence on customer loyalty (CL). Numerous studies have validated this, including Kaura, Prasad, and Sharma (2015), in which SERVQUAL, perceived price, and fairness and service convenience dimensions, had a positive impact on customer satisfaction and customer loyalty in the Indian banking sector. Additionally, the H5 analysis showed that there was a positive relationship between SERVQUAL and CSR. Finally, H6 was shown to have a positive influence on SERVQUAL and customer satisfaction (CS).

\subsection{Corporate social responsibility (CSR)}

Corporate social responsibility (CSR) is having an ever-increasing influence on how consumers view their relationships with the vendors who sell them their products. It has evolved beyond just donating products to the needy, as it now entails community investment through philanthropy, and initiatives focused on enhancing workplace quality. These can also be a significant predictor of firm value (Singh, Sethuraman, \& Lam, 2017).

This is consistent with results from this study, in which it was determined that CSR has a direct and positive influence on customer loyalty (H7), as well as on customer satisfaction (H8). Further support for this comes from Russo and Perrin (2010), in which it was reported that investment in CSR activities could improve the relationship between firms and their stakeholders, and can help the firms secure their critical resources controlled by stakeholders. If resources are allocated to CSR activities, the potential to improve a brand's image and firm public reputation increases (Orlitzky, Schmidt, \& Rynes, 2003). It can also increase an organization's appeal to employees, enhance customer trust (Greening \& Turban, 2000), and consequently boost competitive advantages and improve the firm's financial performance (Bird, Hall, Momentè, \& Reggiani, 2007). 


\subsection{Customer satisfaction (CS)}

Concerning H9 and the hypothesized positive relationship between customer satisfaction (CS) and customer loyalty (CL), this was confirmed. This was consistent with many other studies, such as Kaura et al. (2015), which indicated the importance of customer satisfaction for achieving customer loyalty within a retail environment.

\section{CONCLUSIONS}

The contest between 'bricks versus clicks', with the disruptive effect of e-commerce on traditional retail formats, is starting to be felt in Thailand. These digital citizens have also become homeowners, with the Thai home improvement retail sector emerging as a dynamic and competitive one. In greater Bangkok alone, it was reported that a total of 32,258 condo units were launched in the second half of 2017. Furthermore, an estimated 80,000-100,000 new houses are registered every year. The home improvement industry has rapidly grown in recent years, driven primarily by increasing competition across the country. Retailers are therefore having to adapt by creating unique online shopping experiences, which is enhanced by sophisticated electronic customer relationship management (eCRM)/social media systems designed to capture and retain a digitally savvy Thai consumer. The race is on, the question is which retailer using which methods will win the hearts and minds of the smartphone-addicted consumer?

\section{REFERENCES}

Alireza, F., Fatemeh, B., \& Pegah, M. (2011). How after-sales service quality dimensions affect customer satisfaction. African Journal of Business Management, 5(17), 7658-7664. doi: http://dx.doi.org/10.5897/ajbm11.351.

Anderson, J. C., \& Gerbing, D. W. (1998). Structural equation modeling in practice: A review and recommended a two-step approach. Psychological Bulletin, 103(5), 204 - 215. doi:10.1037/00332909.103.3.411.

Baker, M. (2010). Corporate Social Responsibility - What does it mean? Retrieved from https://tinyurl.com/y8mx5rrq

Baumgartner, H., \& Hombur, C. (1996). Applications of structural equation modeling in marketing and consumer research: A review. International Journal of Research in Marketing, 13, 139-161.

Berry, L. L., Bennet, D. R., \& Brown, C. W. (1989). Service quality: A profit strategy for financial institutions. Homewood, IL: Dow-Jones-Irwin.

Bharadwaj, A., Chaudhary, A., Kittikachorn, P., \& Rastogi, V. (2017). Five Consumer Trends to Watch in Thailand. BCG Center for Customer Insight. Retrieved from https://tinyurl.com/y7yjadcl

Bird, R., Hall, A., Momentè, F., \& Reggiani, F. (2007). What corporate responsibility activities are valued by the market? Journal of Business Ethics, 76(2), 189-206.

doi: http://dx.doi.org/10.1007/s10551-006-9268-1

Bollen, K. A. (1987). Total, direct and indirect effects in structural equation models. Sociological Methodology, 17, 37-69. Retrieved from https://tinyurl.com/ybmyqaol

Byrne, B. M. (2010). Structural equation modeling with AMOS: Basic concepts, applications, and programming ( $2^{\text {nd }}$ d.). New York, NY: Routledge. Retrieved from http://tinyurl.com/ze7ze7d

Chapple, W. \& Moon, J. (2005). Corporate social responsibility (CSR) in Asia: a seven-country study of CSR web site reporting. Business and Society, 44(4), 415-441.

Cherapanukorn, V. (2017). Development of eCRM Success: A Case Study of Hotel Industry. International Journal of Trade, Economics, and Finance, 8(2), 90-95. Retrieved from https://tinyurl.com/y8obooea

Churchill, G. A., \&Surprenant, C. (1982). An investigation into the determinants of customer satisfaction. Journal of Marketing Research, 19(4), 491 - 504. doi: http://dx.doi.org/10.2307/3151722 
Cronan, J. J., Brady, M. K., \&Hult, G. T. M. (2000). Assessing the effects of quality, value, and customer satisfaction on consumer behavioral intentions in service environments. Journal of Retailing, 76(2), 193 - 218. doi: http://dx.doi.org/10.1016/s0022-4359(00)00028-2

Deloitte (2016). The Thailand Consumer Survey: Onwards and upwards. Retrieved from https://tinyurl.com/ycqbynnj

Diamantopoulos, A., \& Siguaw, J. A. (2000). Introducing LISREL. London, UK: Sage.

Electronic Transactions Development Agency. (2016). Value of E-Commerce Survey in Thailand 2016. Retrieved from https://www.etda.or.th

Feinberg, R., \& Kadam, R. (2002). E-CRM Web service attributes as determinants of customer satisfaction with retail websites. International Journal of Service Industry Management, 13(5), 432 - 451. doi: http://dx.doi.org/10.1108/09564230210447922

Girdler, L. (2016, November 5). Lowe's: Leader in home improvement and social media content marketing. Retrieved from https://tinyurl.com/y9pmjtfs

Greening, D. W., \& Turban, D. B. (2000). Corporate social performance as a competitive advantage in attracting a quality workforce. Business \& Society, 39(3), 254-280. doi: http://dx.doi.org/10.1177/000765030003900302

Grönroos, C. (1984). A service quality model and its marketing implications. European Journal of Marketing, 18(4), $36-44$

Grönroos, C. (2001). The perceived service quality concept - a mistake? Managing Service Quality: An International Journal, 11(3), 150-152. doi: http://dx.doi.org/10.1108/09604520110393386

GSB Research. (2016). Industry Monitor (Thai). Retrieved from https://tinyurl.com/y7rkwaor

Hair, J. F., Hult, G. T. M., Ringle, C., \& Sarstedt, M. (2016). A primer on partial least squares structural equation

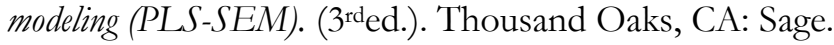

Hallowell, R. (1996). The relationship of customer satisfaction, customer loyalty, and profitability: An empirical study. The International Journal of Service Industry Management, 7(4), 27-42.

Haywood-Farmer, J. (1988). A conceptual model of service quality. International Journal of Operations \& Production Management, 8(6), 19-29.

Holme, R., \& Watts, R. (2000). Making good business sense. World Business Council for Sustainable Development. Retrieved from https://tinyurl.com/yclwz5sv

Hu, L. T., \& Bentler, P. M. (1999). Cutoff criteria for fit indexes in covariance structure analysis: Conventional criteria versus new alternatives. Structural Equation Modeling, 6(1), 1-55. doi: http://dx.doi.org/10.1080/10705519909540118

Jöreskog, K. G., \& Sörbom, D. (2015). LISREL 9.20 for Windows. Skokie, IL: Scientific Software International, Inc.

Kang, G-D., \& James, J. (2004). Service quality dimensions: An examination of Grönroos's service quality model. Managing Service Quality: An International Journal, 14(4), 266 - 277. doi: http://dx.doi.org/10.1108/09604520410546806

Kaura, K., Prasad, Ch. S. D., \& Sharma, S. (2015). Service quality, service convenience, price and fairness, customer loyalty, and the mediating role of customer satisfaction. International Journal of Bank Marketing, 33(4), 404-422. doi: http://dx.doi.org/10.1108/IJBM-04-2014-0048

Kennedy, A. (2006). Electronic customer relationship management. (eCRM): Opportunities and challenges in a digital world. Irish Marketing Review, $18(1$ \& 2), 58-69. Retrieved from https://tinyurl.com/ydfdmu2k

Khadka, K., \& Maharjan, S. (2017). Customer satisfaction and customer loyalty. (Graduate thesis). Centria University of Applied Sciences, Finland. Retrieved from https://tinyurl.com/yae3ns4y

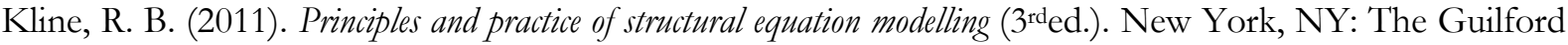
Press.

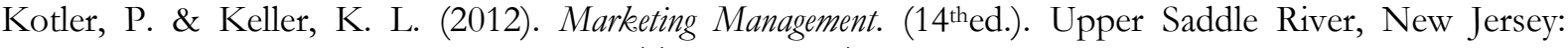
Prentice-Hall. Retrieved from https://tinyurl.com/zgacs7s

Ladhari, R. (2009). A review of twenty years of SERVQUAL research. International Journal of Quality and Service Sciences, 1(2), 172-198. doi:10.1108/17566690910971445

Mano, H., \& Oliver, R. L. (1993). Assessing the dimensionality and structure of the consumption experience: Evaluation, feeling, and satisfaction. Journal of Consumer Research, 20, 451-466. 
Marshall, G, \& Murdoch, I. (2001). Service quality in consulting marketing engineers. International Journal of Construction Marketing, 3(1), 41-49.

Mertler, C. A. (2016). Introduction to Educational Research. Thousand Oaks, CA: Sage Publications.

Ngo, V. M., \& Pavelková, D. (2017). Moderating and mediating effects of switching costs on the relationship between service value, customer satisfaction and customer loyalty: investigation of retail banking in Vietnam. Journal of International Studies, 10(1), $9-33$. doi: https://doi.org/10.14254/2071-8330.2017/10-1/1

Nielsen. (2015). The sustainability imperative: New insights on consumer expectations. Retrieved from https://tinyurl.com/yd56sp9t

Nielsen. (2017). 2016 Nielsen social media report. Retrieved from https://tinyurl.com/mro96g7

OECD. (2006). Quality - ISO. Retrieved from https://tinyurl.com/y8k7pvrd

Oliver, R. L. (1980). A cognitive model of the antecedents and consequences of satisfaction decisions. Journal of Marketing Research, 17, 460-469. doi: http://dx.doi.org/10.2307/3150499

Oliver, R. L. (1994). Conceptual issues in the structural analysis of consumption emotion, satisfaction, and quality: Evidence in a service setting. In C.T. Allen \& D.R. John (Eds.). Advances in Consumer Research, 21. Association for Consumer Research. Provo. UT, 16-22.

Olobatuyi, M. E. (2006). A User's Guide to Path Analysis. Boulder, CO: University Press of America.

Orlitzky, M., Schmidt, F. L., \& Rynes, S. L. (2003). Corporate social and financial performance: A metaanalysis. Organization Studies, 24(3), 403-441. doi: http://dx.doi.org/10.1177/0170840603024003910

Oxford Business Group. (2018). A growth driver: The home improvement segment continues to expand. Retrieved from https://tinyurl.com/y8ukp3n6

Parasuraman, A. Zeithaml, V. A, \& Berry, L. L. (1985). A conceptual model of service quality and its implication. Journal of Marketing, 49(4), 41-50. doi: http://dx.doi.org/10.2307/1251430

Parasuraman, A. Zeithaml, V. A, \& Berry, L. L. (1988). SERVQUAL: A multi-item scale for measuring consumer perception of service quality. Journal of Retailing, 64(1), 12-40. Retrieved from https://tinyurl.com/yb3mj7a7

Pena, M. M., da Silva, E. M. S., Tronchin, D. M. R., \& Melleiro, M. M. (2013). The use of the quality model of Parasuraman, Zeithaml, and Berry in health services.Revista da Escola de Enfermagem da USP, 47(5), 1227 - 1232.

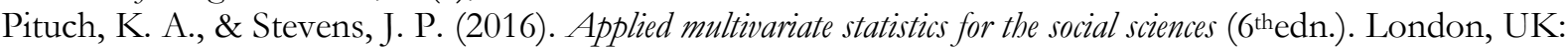
Routledge.

Prahalad, C. K., \& Hamel, G. (1990). The core competence of the corporation. Harvard Business Review, May-June, 79-91.

Pumim, A., Srinuan, C. \& Panjakajornsak, V. (2017). Mobile phone customer loyalty in Thailand: A path analysis case study. Asia-Pacific Social Science Review, 16(3). Retrieved from https://tinyurl.com/y7y9gxz4

Rigby, N. (2018). Home Improvement in Europe: The Amazon Effect. Clavis Insight. Retrieved from https://tinyurl.com/y9ptublm

Russo, A., \&Perrini, F. (2009). Investigating stakeholder theory and social capital: CSR in large firms and SMEs. Journal of Business Ethics, 91 (2), 207-221. doi: http://dx.doi.org/10.1007/s10551-009-0079-z

Skeldon, P. (2017, June 2). 90\% of UK consumers have unsubscribed from retailer comms in the past year. Internet Retailing. Retrieved from https://tinyurl.com/yd2grtbh

Siam Commercial Bank Economic Intelligence Center (2015, May 1). Marketing to Generation Y in Thailand. Retrieved from http://tinyurl.com/o9xfor2

Singh, P., Sethuraman, K., \& Lam, J. (2017). Impact of Corporate Social Responsibility Dimensions on firm value: Some Evidence from Hong Kong and China. Sustainability, 9, 1532 - 1556. doi: http://dx.doi.org/10.3390/su9091532

Siriboon, L. (2018, March 2). Knight Frank Thailand offers Bangkok condominium market outlook. Retrieved from https://tinyurl.com/y9xwx8p9

Stephen, A. T., \& Toubia, O. (2010). Deriving value from social commerce networks. Journal of Marketing Research, 47(2), 215-228. doi: http://dx.doi.org/10.2139/ssrn.1150995

Tavakol, M., \& Dennick, R. (2011). Making sense of Cronbach's alpha. International. Journal of Medical Education, 2, 53-55. doi: http://dx.doi.org/10.5116/ijme.4dfb.8dfd 
Techsauce Team. (2018, February 28). Social media: More than snacks \& selfies! Retrieved from https://tinyurl.com/ybhyq3vq

Thaichon, P., Lobo, A., \& Mitsis, A. (2014). Achieving customer loyalty through service excellence in internet industry. International Journal of Quality and Service Sciences, 6(4), 274-289. doi:http://dx.doi.org/10.1108/ijqss-03-2014-0024

The Nation. (2017, November 21). AmCham Thailand announces finalists for CSR Excellence Awards. Retrieved from https://tinyurl.com/yb2wy3ao

Wang, X., \& Abdullayeva, G. (2011). The relationship between use of social media and customer relationship from ecommerce model perspective. Department of Informatics, Lund University. Retrieved from https://tinyurl.com/ydablsr5

Welford, R. (2005). Corporate social responsibility in Europe, North America, and Asia: 2004 survey results. Journal of Corporate Citizenship, 17(1), 33-52. doi: http://dx.doi.org/10.9774/gleaf.4700.2005.sp.00007

Welter, H., \& Logel, S. (2016, March). Room for improvement. Hardware Retailing. Retrieved from https://tinyurl.com/ya4nk231

Windsor, L. (2017, June 28). The importance of social media in retail. Innovare. Retrieved from https://tinyurl.com/y744hdkz 